\title{
Fósturhjartaómskoðanir á Íslandi 2003-2007; ábendingar og útkoma
}

\section{Sigurveig Pórisdóttir} læknanemi ${ }^{1}$

Hildur Harðardóttir fæðinga- og kvensjúkdómalæknir ${ }^{1,2}$

Hulda Hjartardóttir fæðinga- og kvensjúkdómalæknir²

Óskarsson barnahjartalæknir ${ }^{1,3}$

Hróðmar Helgason barnahjartalæknir ${ }^{3}$

\section{Gunnlaugur Sigfússon} barnahjartalæknir ${ }^{1,3}$

Lykilorð: fósturhjartaómskoðun, ábendingar, meðfæddir hjartagallar.

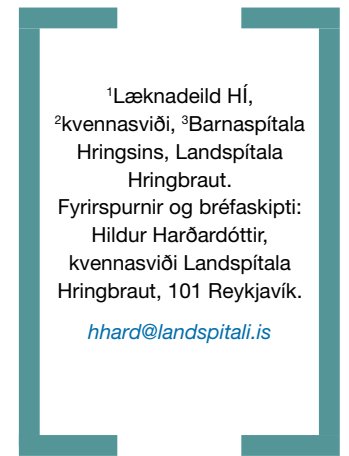

\section{Ágrip}

Inngangur: Í pessari rannsókn voru skoðaðar ábendingar og útkoma fósturhjartaómskoðana og hvaða ábendingum fylgja mestar líkur á hjartagalla.

Efniviður og aðferðir: Farið var yfir ábendingar og útkomu fósturhjartaómana sem gerðar voru á árunum 2003-2007 og hjartagallar sem greindust skráðir. Meðgöngulengd við greiningu, hnakkapykkt fósturs við 12 vikur, afdrif pungunar, niðurstöður krufninga og greining barns eftir fæðingu fengust úr sjúkraskýrslum.

Niðurstöður: Alls voru framkvæmdar 1187 fósturhjartaómskoðanir og greindist hjartagalli í 73 fóstrum. Algengasta ábendingin var fjölskyldusaga um hjartagalla $(631 / 1187 ; 53,2 \%)$ sem leiddi til greiningar 18 hjartagalla í fósturlífi (18/631;2,9\%). Næstalgengasta ábendingin var aukin hnakkapykkt $(159 / 1187 ; 13,4 \%)$ og voru 16 hjartagallar greindir (16/159;10,1\%). Prjátíu konur $(30 / 1187 ; 2,5 \%)$ fóru í fósturhjartaómun vegna óeðlilegrar fjögurra hólfa sýnar sem leiddi til greiningar $22(22 / 30 ; 73,3 \%)$ hjartagalla sem kröfðust inngrips á nýburaskeiði eða höfðu slæmar horfur. Aðrar ábendingar leiddu til greiningar á minniháttar hjartagöllum.

Ályktanir: Óeðlileg fjögurra hólfa sýn er mikilvægasti forspárpátturinn fyrir greiningu hjartagalla í fósturlífi. Sú ábending var aðeins 2,5\% af heildarfjölda fósturhjartaómana á tímabilinu en leiddi til greiningar 30\% allra hjartagalla og voru allir meiriháttar.

\section{Inngangur}

Meðfæddir hjartagallar eru algengastir allra fæðingargalla og valda flestum dauðsföllum. ${ }^{1}$ Á árunum 1990-1999 greindust 740 börn eða 1,7\% lifandi fæddra barna á Íslandi með hjartagalla. ${ }^{2}$ Nýgengi meðfæddra hjartagalla virðist pví vera hærra hér en erlendis par sem talið er að um $1 \%$ lifandi fæddra barna hafi hjartagalla. ${ }^{2-4}$ Stafar petta af auknum fjölda minniháttar hjartagalla en nýgengi alvarlegra hjartagalla er í samræmi við erlendar rannsóknir. ${ }^{2}$ Um priðjungur meðfæddra hjartagalla á Íslandi er meiriháttar og parfnast meðferðar fljótlega eftir fæðingu. ${ }^{2}$ Almennt er talið að helmingur meðfæddra hjartagalla séu meiriháttar. Mikilvægt er að greina alvarlega hjartagalla fyrir fæðingu par sem sýnt hefur verið fram á að pá eru horfur barna betri eftir fæðingu samanborið við börn sem fæðast með ógreindan hjartagalla. ${ }^{5,6}$

Öllum konum er boðin ómskoðun með tilliti til byggingargalla fósturs um miðja meðgöngu. Pá er svokölluð fjögurra hólfa sýn notuð til að meta hvort fjögur hólf hjartans séu til staðar og hvort eðlileg skil séu á milli hólfa og að samræmi sé milli stærðar slegla annars vegar og gátta hins vegar. Rannsóknir á næmi fjögurra hólfa sýnar til að greina byggingargalla í hjarta hafa gefið mjög mismunandi niðurstöður eða á bilinu 15-80\%.-9 Fósturhjartaómskoðun hefur reynst vera áreiðanlegt tæki til greiningar á hjartagöllum á fósturskeiði og gerir kleift að greina fleiri hjartagalla en áður. ${ }^{10}$ Pó greinast flestir meðfæddir hjartagallar eftir fæðingu. 2, $11,12^{2}$

Engar íslenskar rannsóknir hafa verið gerðar á pví hvaða ábendingar fyrir fósturhjartaómskoðunum leiða til flestra greininga hjartagalla á fósturskeiði. Í pessari rannsókn verða skoðaðar algengar ábendingar fyrir fósturhjartaómskoðun og lagt mat á hverjum fylgja mestar líkur á hjartagalla. Pær upplýsingar eru gagnlegar við mat á pví hvaða einstaklingum á öðrum fremur að vísa áfram til fósturhjartaómskoðunar.

\section{Efniviður og aðferðir}

Farið var yfir niðurstöður fósturhjartaómana sem framkvæmdar voru á árunum 2003-2007. Í peim tilfellum par sem hjartagalli fannst voru ábending og niðurstaða rannsóknarinnar skráðar. Ábendingum var skipt í áhættupætti í fjölskyldu, áhættupætti móður og áhættupætti fósturs (tafla I og skífurit). ${ }^{13}$

Upplýsingum um meðgöngulengd við greiningu og hnakkapykkt fósturs við 12 vikna skoðun var aflað úr skrám fósturgreiningardeildar 
Tafla I. Tilvísunarástæður fyrir fósturhjartaómskoðun.

Áhættupættir fjölskyldu

- Áður eignast barn með meðfæddan hjartagalla

- Faðir með̃ meðfæddan hjartagalla

- Erfðasjúkdómar (til dæmis Marfans, Noonans)

Áhættupættir móður

- Móðir með meðfæddan hjartagalla

- Efnaskiptasjúkdómur (til dæmis sykursýki, fenylketónmiga)

- Inntaka fósturskemmandi efna (til dæmis litíum, retinoíðar, flogaveikilyf, áfengi)

- Sýking á meðgöngu (til dæmis rauðir hundar, parvo B19, CMV, toxoplasmosis)

- Sjálfsónæmissjúkdómar (til dæmis rauð̋ir úlfar, Sjögren sjúkdómur)

Áhættupættir fósturs

- Óeðlileg fjögurra hólfa sýn

- Önnur missmíði en á hjarta

- Litningagalli

- Hjartsláttartruflun

- Fósturbjúgur

- Aukin hnakkapykkt

- Fjölburar og TTTS

$\mathrm{CMV=cytomegalovirus;}$ TTTS=twin-to-twin transfusion syndrome
Ábendingar

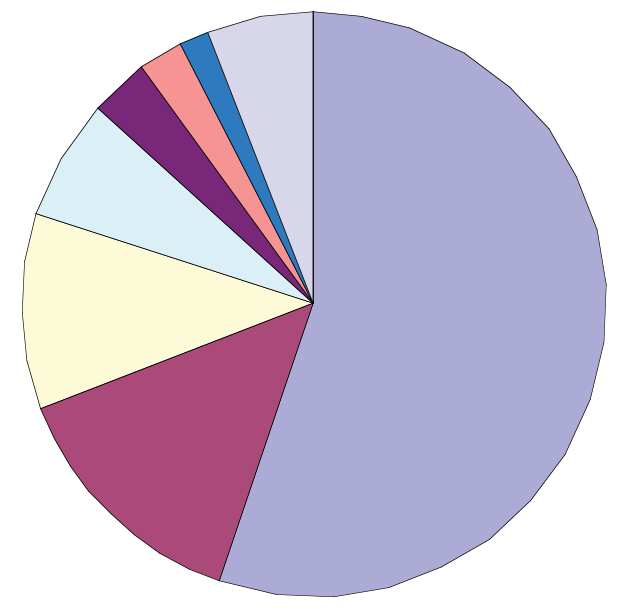

fjölskyldusaga $53,3 \%$

aukin hnakkapykkt

$13,4 \%$

hjartsláttartruflanir

$10,3 \%$

sykursýki móður 6,3\%

lyf á meðgöngu 3,3\%

óeðlileg fjögurra hólfa sýn $2,5 \%$

fjölburar 1,5\%

annað $5,5 \%$
Tafla II. Alpjóðleg heiti hjartagalla og íslenskar pýðingar.

\begin{tabular}{lcc}
\hline Alpjóðlegt heiti & Íslenskt heiti & Skammstöfun \\
\hline Ventricular septal defect & Sleglaskilagalli & VSD \\
\hline Atrial septal defect & Gáttaskilagalli & ASD \\
\hline Atrio-ventricular septal defect & Lokuvísagalli & AVSD \\
\hline Mitral valve regurgitation & Míturlokuleki & MVR \\
\hline Tricuspid atresia & Príblöðkulokun & TAT \\
\hline Interrupted aortic arch & Rof á ósæðarboga & IAA \\
\hline Coarctation aortae & Ósæðarprengsli & CoA \\
\hline Triscuspid regurgitation & Príblöðkulokuleki & TR \\
\hline Hypoplastic left heart syndrome & Vanproska vinstra hjarta & HLHS \\
\hline Pulmonary stenosis & Lungnaslagæðarprengsli & PS \\
\hline Double outlet right ventricle & Tvöfalt útfall hægra slegils & DORV \\
\hline Transposition of the great arteries & Víxlun meginslagæða & TGA \\
\hline Tetrologia of Fallot & Ferna Fallots & TOF \\
\hline Pulmonary atresia & Lungnaslagæðarlokun & PAT
\end{tabular}

Landspítala. Afdrif pungana par sem hjartagalli greindist með fósturhjartaómskoðun voru könnuð og greiningar hjartagalla eftir fæðingu fengin úr sjúkraskýrslum.

Um miðja meðgöngu er öllum konum boðin ómskoðun með tilliti til stærðar fósturs, fylgjustaðsetningar og byggingargalla líffæra, par með talin fjögurra hólfa sýn hjarta. Pessi skoðun er hér kölluð fósturómskimun. Flestar fósturómskimanir eru framkvæmdar af sérpjálfuðum ljósmæðrum sem starfa á fósturgreiningardeild Landspítala. Á landsbyggðinni framkvæma ýmist læknar eða ljósmæður skoðunina. Fósturhjartaómskoðun er framkvæmd af barnahjartalæknum. Auk fjögurra hólfa sýnar er metin tenging stóru æðanna við hjartað, aðlægar bláæðar, prengingar í lokum, lokulekar og virkni hjartavöðva.

Við flokkun á hjartagöllum var stuðst við alpjóðlegt flokkunarkerfi ICD-10 og alpjóðlegar skammstafanir notaðar í megintexta ásamt íslenskum heitum eða pýðingum. Greint er sérstaklega á milli opa í slegli hvort um er að ræða op í vöðvahluta eða nálægt punnum himnuhluta sleglaskila (membranous/perimembranous). Op milli gátta (ASD) er til staðar í fósturlífi og einnig fósturæð. Pví greinast peir gallar ekki með vissu fyrir fæðingu og eru ekki hafðir með í úrtakinu. Op staðsett í neðri hluta gáttaskila (primum ASD) flokkast með gátta- og sleglaskilagalla sem einnig er kallaður lokuvísagalli (AVSD) og er með í pessu úrtaki. Leki á príblöðkuloku milli hægri slegils og hægri gáttar getur verið af lífeðlisfræðilegum ástæðum í fósturlífi án pess að vera byggingargalli. Hér er príblöðkulokuleki ekki hafður með nema um byggingargalla eða mjög marktækan leka sé að ræða. Ef um samsettan hjartagalla er að ræða, pað er fleiri en prír gallar saman, er hann nefndur flókinn samsettur hjartagalli en jafnframt eru erlendar skammstafanir einstakra galla hafðar með innan sviga. Að öðru leyti vísast í töflu II yfir íslenskar pýðingar og alpjóðlegar skammstafanir hjartagalla.

Við vinnslu gagna voru notuð forritin PRISM og Excel. Leyfi voru fengin frá Vísindasiðanefnd Landspítala (16/2009), Persónuvernd og lækningaforstjóra Landspítala.

\section{Niðurstöður}

Alls voru framkvæmdar 15864 fósturómskimanir við 19-20 vikna meðgöngu á fósturgreiningardeild Landspítala á árunum 2003-2007. Par af var 1187 (7,5\%) punguðum konum vísað í fósturhjartaómskoðun hjá barnahjartalæknum á Barnaspítala Hringsins. Fósturhjartaómskoðun leiddi til greiningar hjartagalla í 73 (73/1187;6,1\%) 
tilvikum. Meðalmeðgöngulengd við greiningu var 159 dagar, miðgildi 20 vikur og 2 dagar; (bil $15 \mathrm{v} 2 \mathrm{~d}-38 \mathrm{v} 3 \mathrm{~d})$. Í $71 \%$ tilvika var ómskoðunin framkvæmd milli 18. og 22. viku meðgöngu.

\section{Ábendingar}

Algengasta ábendingin var fjölskyldusaga um meðfæddan hjartagalla, alls 631 (631/1187; 53,2\%). Í pessum hópi hafði 121 kona áður eignast barn með hjartagalla, 73 mæður og 41 faðir voru sjálf með hjartagalla. Í 396 tilvikum var um ótilgreinda og oft óljósa fjölskyldusögu að ræða. Meðfæddur hjartagalli fannst í 18 tilvikum (18/631;2,9\%). Allir gallarnir voru minniháttar (15 VSD, 1 MVR og 1 kransæðafistill) fyrir utan einn galla sem var flókinn samsettur hjartagalli ( DORV, TGA, VSD, PS).

Næstalgengasta ábendingin var aukin hnakkapykkt miðað við meðgöngulengd, 159 tilvik (159/1187;13,4\%). Meðal peirra greindust 16 einstaklingar (16/159;10,1\%) með hjartagalla við fósturhjartaómskoðun. Par af voru 12 VSD, tveir primum ASD, ein lokuð príblöðkuloka og einn lokuvísagalli.

Í 30 tilvikum (30/1187;2,5\%) var fósturhjartaómskoðun gerð vegna óeðlilegrar fjögurra hólfa sýnar við 20 vikna fósturómskimun. Af peim voru $22(22 / 30 ; 73,3 \%)$ greindir með hjartagalla við fósturhjarta-ómskoðun. Öll fóstrin reyndust vera með meiriháttar hjartagalla sem fylgdu slæmar horfur. Mörg peirra pörfnuðust aðgerðar fljótlega eftir fæðingu. Til samanburðar leiddu allar aðrar ábendingar til greiningar sjö meðfæddra hjartagalla sem höfðu mjög slæmar horfur eða kröfðust inngrips skömmu eftir fæðingu. Tafla III sýnir allar tilvísunarástæður í algengisröð.

\section{Gerðir hjartagalla}

Algengasti hjartagallinn sem fannst með fósturhjartaómskoðun var VSD (36/73; 49\%), par af voru 22 í vöðvahluta sleglaskilanna (muscular VSD) en 14 í pynnri efri hluta (membranous VSD). Eftir fæðingu voru fimm peirra enn til staðar, fjórir í vöðvahluta sleglaskila og einn í efri hluta peirra. Allir meiriháttar hjartagallar voru staðfestir eftir meðgöngulok ýmist meðómskoðun eða krufningu. Tafla IV sýnir gerðir og algengi hjartagalla sem voru greindir í fósturhjartaómskoðun.

\section{Litningagallar}

Meðal peirra fóstra sem greindust með hjartagalla voru sex með litningagalla. Prjú voru með prístæðu 21, tvö með einstæðu X (Downs heilkenni) og eitt með prístæðu 18. Tvö fóstranna með prístæðu 21 voru greind með VSD í fósturhjartaómskoðun og eitt peirra með lokuvísagalla. Annað fóstranna
Tafla III. Tilvísunarástæður og fjöldi greininga.

\begin{tabular}{|c|c|c|c|}
\hline \multicolumn{4}{|c|}{15.864 fósturómskimanir } \\
\hline Tilvísunarástæður & $\begin{array}{c}\text { Vísad í FHÓ } \\
n=1187\end{array}$ & MHG n=73 (\%) & $\begin{array}{c}\text { Hlutfall af } \\
\text { heildarfjölda } \\
\text { greininga í FHÓ, \% }\end{array}$ \\
\hline Fjölskyldusaga um MHG & 631 & $18(2,9)$ & 24,7 \\
\hline Aukin hnakkapykkt & 159 & $16(10,1)$ & 21,9 \\
\hline Hjartsláttartruflanir & 122 & $5(4,1)$ & 6,8 \\
\hline Sykursýki móður & 75 & 0 & 0 \\
\hline - IDDM & 47 & 0 & 0 \\
\hline - GDM & 28 & 0 & 0 \\
\hline Aðrar vanskapanir & 48 & $2(4,3)$ & 2,7 \\
\hline Lyf á meðgöngu & 39 & $410,3)$ & 5,5 \\
\hline Óeðlileg fjögurra hólfa sýn & 30 & $22(73,3)$ & 30,1 \\
\hline Fjölburar & 18 & 0 & 0 \\
\hline Ađrir sjúkdómar móður* & 12 & $1(8,3)$ & 1,4 \\
\hline Fósturbjúgur & 6 & $2(33,3)$ & 2,7 \\
\hline Litningagallar & 4 & $3(75)$ & 4,1 \\
\hline Ótilgreint & 44 & 0 & 0 \\
\hline
\end{tabular}

Tafla IV. Hjartagallar greindir með fósturhjartaómskoðun.

\begin{tabular}{lc}
\hline MHG & Fjöldi; N = 73 (\%) \\
\hline VSD & $36(49,3)$ \\
\hline - perimembranous & $14(19,2)$ \\
\hline - vöðvahluti & $22(30,1)$ \\
\hline Primum ASD & $2(2,7)$ \\
\hline Ósæðarprengsli (CoA) & $2(2,7)$ \\
\hline Ebstein hjartagalli & $2(2,7)$ \\
\hline Vanproska vinstra hjarta (HLHS) & $9(12,3)$ \\
\hline Flókinn samsettur galli & $7(9,6)$ \\
\hline Opleysi ósæðarboga (IAA) & $1(1,4)$ \\
\hline Lungnaslagæðarlokuprengsli & $1(1,4)$ \\
\hline Lokuð lungnastofnsloka og VSD & $1(1,4)$ \\
\hline Lokuð lungnastofnsloka & $2(2,7)$ \\
\hline Lokuð príblöðkuloka (TAT) & $2(2,7)$ \\
\hline Byggingargalli príblöðkuloku (TVA) & $1(1,4)$ \\
\hline Lokuvísagalli (AVSD) & $3(4,1)$ \\
\hline Míturlokuleki (MVR) & $2(2,7)$ \\
\hline Kransæðafistill & $1(1,4)$ \\
\hline Ferna Fallots (TOF) & $1(1,4)$ \\
\hline $\begin{array}{l}\text { MHG = meðfæddur hjartagalli; VSD = ventricular septal defect; ASD } \\
\text { = atrial septal defect; CoA = coarctation aortae; }\end{array}$ & \\
arch; = TAT = tricuspid atresia; TVA = tricuspid valve abnormality; \\
regurgitation; TOF = tetrologia of Fallot.
\end{tabular}

með Turner heilkenni hafði ósæðarprengsli en hitt hafði lokaða lungnastofnsloku. Fóstrið með prístæðu 18 hafði flókinn samsettan hjartagalla með einhólfa hjarta. Prístæða 21 var pekkt í tveimur tilvikum af premur fyrir fósturhjartaómskoðun. 
Sterkur grunur var um prístæðu 21 í priðja tilvikinu vegna óeðlilegrar fjögurra hólfa sýnar og gruns um lokuvísagalla, en litningapróf var afpakkað. Einstæða $X$ var greind eftir fæðingu annars vegar og við rannsókn eftir fóstureyðingu hins vegar. Ástæður fyrir fósturhjartaómskoðun voru fósturbjúgur og óeðlileg fjögurra hólfa sýn í pessum tveimur tilvikum. Prjú börn höfðu genagalla, meðfæddan Marfans sjúkdóm, CATCH22 og CHARGE heilkenni greint eftir fæðingu.

\section{Afdrif pungana}

Af peim 73 pungunum par sem ómun sýndi fram á hjartagalla fæddu 54 konur (73,9\%) lifandi börn, par af voru tvennir tvíburar. Tólf barnanna fóru í aðgerð vegna hjartagalla skömmu eftir fæðingu (12/54; 22,2\%). Í pessum tilvikum var um að ræða fernu Fallots (tetralogia of Fallot), rof á ósæðarboga (interrupted aortic arch), lokaða lungnaslagæð (pulmonary atresia), lokaða lungnaslagæð og VSD, prengsli á lungnastofnsloku (pulmonary stenosis), ósæðarprengsli (coarctatio aortae), primum ASD og príblöðkulokuleka (tricuspid regurgitation). Fjögur börn höfðu flóknari samsetta hjartagalla. Tvö barnanna létust skömmu eftir aðgerð. Eitt barn úr rannsóknarhópnum fæddist andvana, pað hafði prístæðu 18.

Endir var bundinn á meðgöngu í 18 tilvikum, vegna hjarta- eða litningagalla sem hafði slæmar horfur (18/73; 24,7\%). Í 15 tilvikum par sem fóstureyðing var gerð var tilvísunarástæðan óeðlileg fjögurra hólfa sýn við 20 vikna ómskimun. Í tveimur tilvikum var tilvísunarástæðan aukin hnakkapykkt við 12 vikur, við 20 vikur kom í öðru tilfellinu fram óeðlileg fjögurra hólfa sýn en takttruflun í hinu. Ein fóstureyðing var gerð vegna prístæðu 21. Tíu fóstranna höfðu vanproska vinstra hjarta, (hypoplastic left heart syndrome), eitt hafði lokaða príblöðkuloku (tricuspid atresia), fjögur voru með flókna samsetta hjartagalla og eitt með lokaða lungnaslagæð og vanproska hægra hjarta (pulmonary atresia, hypoplastic right heart). Eitt fóstur hafði alvarlegan Ebstein hjartagalla og lífslíkur voru afar slæmar. Greining meiriháttar hjartagalla var staðfest með krufningu í öllum tilvikum.

\section{Umræða}

Óeðlileg fjögurra hólfa sýn við fósturómskimun um miðja meðgöngu leiddi hlutfallslega til greiningar flestra hjartagalla í fósturlífi. Ef fjögurra hólfa sýn var óeðlileg leiddi pað til greiningar hjartagalla í $73 \%$ tilvika og voru allir meiriháttar. Sú ábending var aðeins um 2,5\% af heildarfjölda ómana en leiddi til greiningar um $30 \%$ allra hjartagalla. Petta er í samræmi við niðurstöður annarra rannsókna sem hafa sýnt háa greiningartíoni (detection rate) óeðlilegrar fjögurra hólfa sýnar, eða á bilinu 49$77 \%{ }^{11,14-16}$

Hjartsláttartruflun hjá fóstri leiddi til til greiningar hjartagalla í fimm tilvikum af 122 (6,9\%) en prír af fimm hjartagöllum reyndust vera meiriháttar (lokuvísagalli, ferna Fallots, Ebsteins hjartagalli).

Algengar ábendingar fyrir fósturhjartaómun, svo sem fjölskyldusaga um meðfæddan hjartagalla, sykursýki móður og lyfjanotkun á meðgöngu, leiddu yfirleitt til greiningar minniháttar hjartagalla. Algengasta ábendingin, fjölskyldusaga um hjartagalla, leiddi aðeins til greiningar í um 3\% tilvika og í öllum tilvikum nema einu var gallinn minniháttar. Engir hjartagallar greindust vegna ábendinganna sykursýki móður, fjölburar og heilkenni blóðtilfærslu milli tvíbura (twin-totwin transfusion syndrome) og aðrir sjúkdómar móður. Fósturhjartaómanir sem gerðar voru vegna notkunar flogalyfja leiddu til greiningar fjögurra VSD sem allir voru lokaðir eftir fæðingu.

Sykursýki móður er algeng tilvísunarástæða fyrir fósturhjartaómskoðun en í okkar hópi greindist ekkert fóstur með hjartagalla og kemur pað nokkuð á óvart. Vel er pekkt að sykursýki móður felur í sér allt að prefalda hættu á hjartagalla hjá fóstri. ${ }^{17}$ Petta gæti bent til betri blóðsykurstjórnar en áđur hjá punguðum konum en einnig gæti lítið pýði skýrt að enginn hjartagalli fannst.

Pær rannsóknir sem birtar hafa verið um ábendingar fyrir fósturhjartaómskoðunum hafa greint frá mismunandi niðurstöðum hvað varðar algengi tilvísunarástæðna. Greint var frá pvíi nýlegri rannsókn að hjartsláttartruflun fósturs væri algengasta ábendingin fyrir fósturhjartaómskoðun og leiddi til greiningar hjartagalla í 2,5\% tilvika, næstalgengasta tilvísunarástæðan var óeðlileg fjögurra hólfa sýn. ${ }^{11}$ Í annarri nýlegri rannsókn var algengasta tilvísunarástæðan fyrir fósturhjartaómskoðun óeðlileg fjögurra hólfa sýn við ómskimun og var sú ábending einnig talin gagnlegri við að finna meðfædda hjartagalla en aðrir áhættupættir. ${ }^{14}$ Fjölskyldusaga var næstalgengasta tilvísunarástæðan með tæplega tveggja prósenta grein-

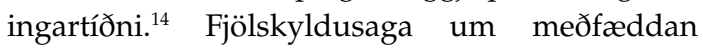
hjartagalla var algengasta tilvísunarástæðan (34\%) og hafði greiningartíðni um 1\% 1́ eldri rannsókn frá 1995. ${ }^{15}$ Margar rannsóknir hafa sýnt fram á mikilvægi fjögurra hólfa sýnar við greiningu hjartagalla í fósturlífi ${ }^{11,14,16,18}$ og er pað í samræmi við niðurstöður pessarar rannsóknar.

Aukin hnakkapykkt við 12 vikna ómskoðun er vísbending um litningagalla fósturs en einnig 
meðfædda hjartagalla. ${ }^{19-21}$ Í okkar rannsóknarpýði fannst meðfæddur hjartagalli í fósturhjartaómun hjá 10\% peirra (16 af 159) sem sendir voru í rannsóknina vegna aukinnar hnakkapykktar. Fjórir voru meiriháttar (4/159; 2,5\%). Makrydimas greindi frá pví að búast mætti við pví að greina einn meiriháttar hjartagalla hjá hverjum 33 (1/33; $3 \%$ ) fóstrum sem vísað er í fósturhjartaómun vegna aukinnar hnakkabykktar. ${ }^{22}$ Í okkar pýði greindust 12 litlir VSD pegar ábendingin var aukin hnakkapykkt sem allir höfðu lokast eftir fæðingu. Út frá pví má álykta að prátt fyrir að aukinni hnakkapykkt fylgi auknar líkur á meðfæddum hjartagalla er oftar um minniháttar vandamál að ræða.

Erfitt getur verið að greina VSD í fósturlífi par sem prýstingur er jafn í báðum sleglum á peim tíma og pví lítið flæði um slík op pótt pau séu til staðar. Ef ekki var hægt að staðfesta VSD í næstu skoðunum var erfitt að segja til um hvort opið hefði lokast af sjálfu sér eða ekki verið til staðar til að byrja með. Рað er pví viss hætta á ofgreiningu á VSD í pessari rannsókn sem taka verður með fyrirvara. Einnig ber að geta pess að greining VSD fyrir fæðingu hefur aðeins minniháttar pýðingu og engra sérstakra ráðstafana varðandi meðgöngu og fæðingarmáta er pörf. Horfur barna með VSD eru góðar hvort sem opið er greint fyrir eða eftir fæðingu.

Hjartagallar eru hluti af ýmsum meðfæddum heilkennum, finnist hjartagalli hjá fóstri kallar pað á leit að frekari missmíðum og í sumum tilvikum litningarannsóknir. Sex fóstur greindust með litningagalla í rannsóknarhópnum og prjú með genagalla, 12,3\% (9 af 73). Er pað nokkru minni fjöldi en aðrar rannsóknir hafa greint frá en Moore fann litningagalla eða genagalla hjá $41 \%$ fóstra sem greindust með hjartagalla í fósturlífi. ${ }^{23}$ Pennan mun má að nokkru leyti skýra með pví að á Íslandi eru allar fósturhjartaómskoðanir gerðar á einum stað. Раð er pví óvalinn hópur sem kemur til skoðunar, en víða erlendis er um valdar tilvísanir til mjög sérhæfðra stofnana að ræða. Ennfremur er skýring fólgin í pví að á pessum tíma fóru um 70\% kvenna í ómskoðun og sampætt líkindamat til að meta líkur á litningagöllum fósturs við 12 vikur. Pví má búast við að stór hluti litningagalla hafi pegar komið fram fyrir 20 vikna skoðunina.

Erlendar rannsóknir hafa sýnt að börnum með alvarlegan meðfæddan hjartagalla farnast betur ef gallinn er pekktur fyrir fæðingu. ${ }^{5,6}$ Tilgangur fósturhjartaómskoðunar er pví fyrst og fremst аð auka lífslíkur og lífsgæði einstaklingsins. Ef alvarlegur hjartagalli er staðfestur er fæðing á Landspítalanum æskileg par sem nýburagjörgæsla er til staðar og unnt er að veita meðferð strax eftir fæðingu. Jafnframt er mikilvægt að fræða og undirbúa foreldra fyrir fæðingu barns síns pví í mörgum tilvikum purfa peir að fara utan með nýfætt barn sitt í erfiðar aðgerðir.

Um 75\% allra pungaðra kvenna á Íslandi koma á fósturgreiningardeild kvennadeildar Landspítala við 20 vikur. Paðan koma flestar ábendingar um fósturhjartaómskoðun. Á Íslandi eru fósturhjartaómskoðanir aðeins framkvæmdar á Barnaspítala Hringsins og pangað koma pví öll börn með hjartagalla hvort sem greining er gerð fyrir eða eftir fæðingu. Pví er einstakt að geta skoðað ábendingar og útkomu fósturhjartaómskoðana meðal heillar pjóðar.

Niðurstöður rannsóknarinnar benda til pess að aukin hnakkapykkt sé ekki eins sterk vísbending um alvarlega hjartagalla og áður var talið. Fjöldi fósturhjartaómskoðana sem gerðar eru vegna fjölskyldusögu en hlutfallslega fáar greiningar benda til að prengja megi pennan hóp. Við leggjum til að ábending fyrir fósturhjartaómun sé aðeins nauðsynleg ef jákvæð ættarsaga um meðfædda hjartagalla er í fyrsta ættlið, eins og kemur fram í töflu I. Óeðlilegri fjögurra hólfa sýn fylgja mun meiri líkur á alvarlegum hjartagalla en nokkurri annarri ábendingu sem sýnir mikilvægi pess að skoða fósturhjartað við reglubundna 20 vikna ómskimun.

\section{Pakkir}

Kærar pakkir fá starfsfólk fósturgreiningardeildar, Guðrún Garðarsdóttir, ritari fæðingarskrár, og Anna Haarde, skrifstofustjóri á kvennasviði Landspítala.

\section{Heimildir}

1. Lee K, Khoshnood B, Chen L, Wall SN, Cromie WJ, Mittendorf RL. Infant mortality from congenital malformations in the United States, 1970-1997. Obstet Gynecol 2001; 98: 620-7.

2. Stephensen SS, Sigfússon G, Eiríksson H, et al. Nýgengi og greining meðfæddra hjartagalla á Íslandi 1990-1999. Læknablaðið 2002; 88: 281-7.

3. Dulskiene V, Malinauskiene V, Azaraviciene A, Kuciene R. [The incidence and diagnostics of congenital heart defects in Kaunas infant population during 1999-2005]. Medicina (Kaunas) 2008; 44: 139-46. Litháíska

4. Hoffman JI, Kaplan S. The incidence of congenital heart disease. J Am Coll Cardiol 2002; 39: 1890-900.

5. Eapen RS, Rowland DG, Franklin WH. Effect of prenatal diagnosis of critical left heart obstruction on perinatal morbidity and mortality. Am J Perinatol 1998; 15: 237-42.

6. Mahle WTC, Robert R; McGaurn, et al. Impact of prenatal diagnosis on survival and early neurologic morbidity in neonates with the hypoplastic left heart syndrome. Pediatrics 2001; 107: 1277-82.

7. Todros T, Faggiano F, Chiappa E, Gaglioti P, Mitola B, Sciarrone A. Accuracy of routine ultrasonography in screening heart disease prenatally. Gruppo piemontese for prenatal screening of congenital heart disease. Prenat Diagn 1997; 17: 901-6.

8. Randall P, Brealey S, Hahn S, Khan KS, Parsons JM. Accuracy of fetal echocardiography in the routine detection of congenital heart disease among unselected and low risk populations: A systematic review. BJOG 2005; 112: 24-30. 
9. Tegnander E, Williams W, Johansen OJ, Blaas HG, Eik-Nes $\mathrm{SH}$. Prenatal detection of heart defects in a non-selected population of 30,149 fetuses - detection rates and outcome. Ultrasound Obstet Gynecol 2006; 27: 252-65.

10. McAuliffe FM, Trines J, Nield LE, Chitayat D, Jaeggi E, Hornberger LK. Early fetal echocardiography - a reliable prenatal diagnosis tool. Am J Obstet Gynecol 2005; 193: 125359.

11. Li M, Wang W, Yang X, Yan Y, Wu Q. Evaluation of referral indications for fetal echocardiography in beijing. J Ultrasound Med 2008; 27: 1291-6.

12. Garne E, Stoll C, Clementi M. Evaluation of prenatal diagnosis of congenital heart diseases by ultrasound: Experience from 20 european registries. Ultrasound Obstet Gynecol 2001; 17: 386-91.

13. Rychik J, Ayres N, Cuneo B, et al. American society of echocardiography guidelines and standards for performance of the fetal echocardiogram. J Am Soc Echocardiogr 2004; 17: 803-10.

14. Simpson LL. Indications for fetal echocardiography from a tertiary-care obstetric sonography practice. J Clin Ultrasound 2004; 32: 123-8.

15. Cooper MJ, Enderlein MA, Dyson DC, Roge CL, Tarnoff $\mathrm{H}$. Fetal echocardiography: Retrospective review of clinical experience and an evaluation of indications. Obstet Gynecol 1995; 86: 577-82

16. Perri T, Cohen-Sacher B, Hod M, Berant M, Meizner I, Bar J. Risk factors for cardiac malformations detected by fetal echocardiography in a tertiary center. J Matern Fetal Neonatal Med 2005; 17: 123-8.
17. Macintosh MC, Fleming KM, Bailey JA, et al. Perinatal mortality and congenital anomalies in babies of women with type 1 or type 2 diabetes in england, wales, and northern ireland: Population based study. BMJ 2006; 333: 177.

18. Friedberg MK, Silvermann NH. Changing indications for fetal echocardiography in a University Center population. Prenat Diagn 2004; 24: 781-6.

19. Bahado-Singh RO, Wapner R, Thom E, et al. Elevated firsttrimester nuchal translucency increases the risk of congenital heart defects. Am J Obstet Gynecol 2005; 192: 1357-61.

20. Makrydimas G, Sotiriadis A, Huggon IC, et al. Nuchal translucency and fetal cardiac defects: A pooled analysis of major fetal echocardiography centers. Am J Obstet Gynecol 2005; 192: 89-95.

21. McAuliffe FM, Hornberger LK, Winsor S, Chitayat D, Chong K, Johnson JA. Fetal cardiac defects and increased nuchal translucency thickness: A prospective study. Am J Obstet Gynecol 2004; 191: 1486-90.

22. Makrydimas G, Sotiriadis A, Ioannidis JP. Screening performance of first-trimester nuchal translucency for major cardiac defects: a meta-analysis. Am J Obstet Gynecol 2003; 189: 1330-5.

23. Moore JW, Binder GA, Berry R. Prenatal diagnosis of aneuploidy and deletion 22q11.2 in fetuses with ultrasound detection of cardiac defects. Am J Obstet Gynecol 2004; 191: 2068-73

\section{Fetal Echocardiography in Iceland 2003-2007; indications and outcomes}

Objective: The aim of the study was to evaluate the indications and outcomes of fetal echo (FE) and determine which indication has the highest detection rate for congenital heart disease (CHD).

Methods: The referral indications and results of $\mathrm{FE}$ performed in Iceland during 2003-2007 were reviewed. Information regarding gestational age at diagnosis, nuchal translucency, pregnancy outcome, autopsy results and postnatal diagnosis were obtained from medical records. Results: During the five year period 1187 FE were performed. Structural heart defect was diagnosed in 73 fetuses. The most common referral indication was family history of $\mathrm{CHD}(631 ; 53.2 \%)$ which led to diagnosis of 18 heart defects prenatally (2.9\%). The second most common referral indication was increased nuchal translucency (159) and abnormal cardiac findings were present in 16 cases (10.1\%). A total of 30 women were referred for FE because of abnormal four chamber view (AFCV) which resulted in the diagnosis of 22 (73.3\%) major heart defects, either incompatible with life or requiring immediate intervention after birth. Other indications led mostly to the diagnoses of minor defects.

Conclusions: AFCV is the most important predictor for diagnosis of structural heart defects. 2,5\% were referred for FE due to AFCV which led to diagnosis of $30 \%$ of all heart defects, all of which were major.

Thorisdottir S, Hardardottir H, Hjartardottir H, Oskarsson G, Helgason H, Sigfusson G.

Fetal Echocardiography in Iceland 2003-2007; indications and outcomes. Icel Med J 2010; 93-8

Key words: fetal echocardiography, indications, congenital heart disease.

Correspondence: Hildur Harðardóttir, hhard@landspitali.is 